Terbit online pada laman web jurnal: http://jurnal.iaii.or.id

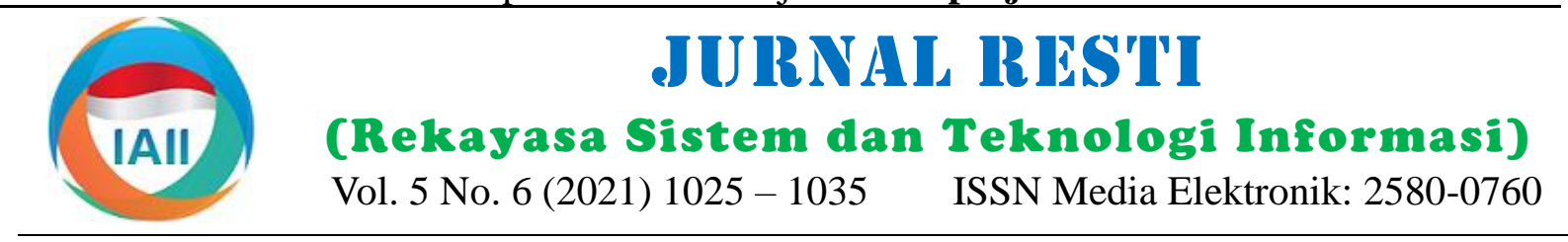

\title{
Sistem Pendistribusian Air Bersih Metode Prabayar Terkendali Mikrokontroler Berbasis IoT
}

\author{
Efrizon $^{1}$, Muhammad Irmansyah ${ }^{2}$, Anggara Nasution $^{3}$, Era Madona $^{4}$, Anggi Lifya Rani ${ }^{5}$ \\ 1,2,3,4,5 Jurusan Teknik Elektro Politeknik Negeri Padang \\ ${ }^{1}$ efrizonsyofyan@gmail.com, ${ }^{2}$ anggara@pnp.ac.id, ${ }^{3}$ emadona38@gmail.com
}

\begin{abstract}
A number of problems sometimes often arise regarding the flow of clean water from Regional Drinking Water Companies (PDAMs) to customers, such as the flow of water stops suddenly or there is no water at all, so it is necessary to manufacture a prototype system for monitoring the distribution of clean water with a microcontroller-controlled prepaid method. IoT based. The distribution of PDAM water that is channeled to consumers can be monitored online through the Internet network. The objectives of this research are (a) to make a prototype (prototype) of a prepaid clean water distribution system controlled by a microcontroller based on IoT, (b) to program an Arduino IDE-assisted system, and (c) to measure system performance. The research method starts from making a prototype physical form of clean water distribution assisted by a microcontroller, programming the microcontroller and Wi-Fi module, and measuring system performance. The results of measuring system performance are indicated by an error in the ultrasonic sensor reading HC-SRO4 that occurs when the water level is low and too high with a maximum measured water level of $95 \%$. The error when measuring the waterflow sensor at the water level is lower than $49 \%$ which is influenced by the water speed from the low pressure pump when the water level is below that value. The accuracy level of the waterflow sensor is $96.96 \%$ which is based on the sensor measurement results which are compared to the measurement results with a measuring cup. The system can monitor data readings from the waterflow sensor by using the NodeMCU ESP8266 on a web server from Thinkspeak via the smartphone screen. Overall the tool can function well.
\end{abstract}

Keywords: NodeMCU ESP8266, IoT, microcontroller, prepaid method water distribution.

\begin{abstract}
Abstrak
Sejumlah masalah terkadang sering timbul berkenaan dengan pengaliran air bersih dari Perusahaan Daerah Air Minum (PDAM) ke pelanggan, seperti aliran air terhenti secara tiba-tiba atau ketiadaan air sama sekali, sehingga perlu dilakukan pembuatan purwarupa sistem untuk pemantauan pendistribusian air bersih metode prabayar terkendali mikrokontroler berbasis IoT. Pendistribusian air PDAM yang teralirkan ke konsumen dapat dipantau secara online melalui jaringan Internet. Sasaran penelitian ini, yaitu (a) membuat sebuah purwarupa (prototipe) sistem pendistribusian air bersih metode prabayar terkendali mikrokontroler berbasis IoT, (b) memrograman sistem berbantuan Arduino IDE, dan (c) mengukur kinerja sistem. Metode penelitian dimulai dari pembuatan wujud fisik purwarupa distribusi air bersih berbantuan mikrokontroler, pemrograman terhadap mikrokontroler dan modul Wi-Fi, dan pengukuran kinerja sistem. Hasil pengukuran kinerja sistem ditunjukkan dengan kesalahan pembacaan sensor ultrasonik HC-SR04 terjadi saat level air kondisi rendah dan terlalu tinggi dengan ketinggian air terukur maksimal sebesar 95\%. Kesalahan saat pengukuran sensor waterflow pada ketinggian air lebih rendah dari $49 \%$ yang dipengaruhi oleh kecepatan air dari pompa dengan tekanan rendah saat ketinggian air di bawah nilai tersebut. Tingkat akurasi sensor waterflow sebesar $96,96 \%$ yang didasarkan kepada hasil pengukuran sensor yang dibandingkan terhadap hasil ukur dengan gelas ukur. Sistem dapat untuk pemantauan pembacaan data dari sensor waterflow dengan penggunaan NodeMCU ESP8266 pada web server dari Thinkspeak melalui layar smartphone. Secara keseluruhan alat dapat berfungsi dengan baik.
\end{abstract}

Kata kunci: NodeMCU ESP8266, IoT, mikrokontroler, pendistribusian air dengan metode prabayar.

\section{Pendahuluan}

rumah warga (pelanggan, konsumen), seperti aliran air Pendistribusian air bersih selama ini diselenggarakan terhenti secara tiba-tiba atau ketiadaan air sama sekali, oleh pemerintah melalui Perusahaan Daerah Air Minum sehingga konsumen sering komplain dan kecewa (PDAM). Sejumlah masalah terkadang sering timbul terhadap pelayanan dari perusahaan tersebut. berkenaan dengan pengaliran air bersih dari PDAM ke Berdasarkan kondisi tersebut, dipabrikasi alat 
pemantauan (monitoring) penggunaan air PDAM yang ESP8266. Diagram skematis sistem pengontrol teralirkan ke konsumen, sehingga dapat dipantau secara pendistribusian air PDAM prabayar, seperti ditunjukkan online melalui jaringan Internet. Pabrikasi alat pada Gambar 1.

pemantauan juga didukung oleh perkembangan teknologi informasi melalui kehadiran inovasi teknologi, salah satunya berupa Internet of thing (IoT) [1]. Saat ini IoT telah diimlementasi pada bidang pertanian [2], kesehatan [3], monitoring parkir [4], dan industry [5] dengan dukungan teknologi IoT untuk pemantauan [6] dan pengkontrolan [7].

Penelitian terkait dengan distribusi air telah dilakukan sebelumnya, seperti sistem pemantauan air secara realtime berbasis web[8] dengan penempatan sensor MPX5700AP untuk pengukuran tekanan air. Modul Global System for Mobile Commuication/General Packet Radio Service (GSM/GPRS) digunakan untuk komunikasi antara sistem dan server melalui jaringan GSM/GPRS. Penunjukan hasil penelitian berupa nilai pengukuran tekanan air dan grafik tertampilkan pada $w e b$. Penelitian lain berupa pembuatan prototipe untuk sistem pemantauan air berbasis model berbasis IoT[9]. Prototipe terpabrikasi berbantuan sensor ultrasonik untuk deteksi level air, modul GSM untuk kirim pesan ketika terdapat aktivitas pada pompa air.

Pembuatan sistem monitoring dan pengendalian berbasis NodeMCU ESP8266 untuk pendistribusian air melalui pengaturan debit air dan zona waktu untuk pendistribusian air ke konsumen [10]. Debit air dideteksi oleh sensor waterflow, sedangkan valve terhubung dengan motor servo, dan modul RTC DS1307 untuk penunjukan zona waktu. Penelitian terkait dengan pemantauan level air telah direalisasikan melalui Smart Water Level Controlling System [WLCS] berbasis IoT untuk pengukuran level air dan pengontrolan pengisian ke tangki air [11]. Penelitian serupa untuk pemantauan ketinggian air secara otomatis [12]. Sensor ultrasonik HC-SR04 untuk deteksi ketinggian air, jika tandon air penuh atau level $100 \%$ tercapai, maka sensor pendeteksi ketinggian air dan pompa supply air otomatis berhenti beroperasi.

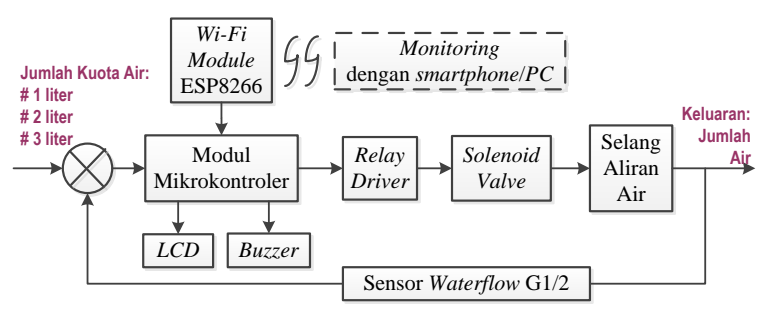

Gambar 1. Diagram skematis sistem pengontrol pendistribusian air PDAM prabayar

Berdasarkan Gambar 1 dapat dijelaskan, bahwa sensor waterflow dipasang untuk pengukuran debit air berdasarkan kecepatan aliran air dan sisa kuota air di masing-masing pelanggan dan ditampilkan dalam bentuk digital, terkendali mikrokontroler. Pendistribusian air bersih PDAM berdasarkan pembelian kuota air sesuai harga jual di lingkungan PDAM dengan satuan meter kubik $\left(\mathrm{m}^{3}\right)$ atau seribu liter. Satuan pada prototipe sistem diverifikasi melalui satuan liter air yang setara dengan satu meter kubik, melalui miniatur penyediaan air pada galon berukuran 19 liter untuk perolehan hasil pengukuran kinerja prototipe sistem melalui simulasi.

Berpedoman kepada proses peng-input-an kuota air dari serial monitor pada aplikasi Arduino diubah melalui halaman web dengan jaringan Local Area Network $(L A N)$, penambahan mekanisme pengendalian pompa air, dari kondisi selalu aktif menjadi nonaktif, ketika kepemilikan kuota air dan aliran air terhenti saat kuota air habis [10]. Pemantauan volume air sesuai kuota dilakukan melalui NodeMCU ESP8266 berbasis aplikasi Thingspeak, sehingga ditetapkan tujuan penelitian yang meliputi (a) membuat sebuah prototipe sistem pendistribusian air bersih metode prabayar terkendali mikrokontroler berbasis $I o T$, (b) pemrograman sistem berbantuan Arduino IDE, dan (c) mengukur kinerja sistem berupa hasil pengukuran terhadap ketinggian air Pembuatan prototipe sistem keran air otomatis untuk dan dapat dipantau di komputer berbasis jaringan, dan gedung bertingkat [13] dengan hasil berupa penunjukan penampilan pembacaan kuota air bersih yang terdapat di sistem kontrol untuk pengaturan jadwal buka atau tutup meteran air pada Liquid Crystal Display (LCD).

keran air secara otomatis maupun manual dan pembatasan volume air pada masing-masing keran. Sensor flowmeter digunakan untuk menghitung debit air. Volume air dihitung dengan menambahkan debit air yang melewati sensor. Komunikasi serial digunakan untuk mengirimkan data dari arduino ke personal computer (PC).

Berdasarkan sejumlah hasil penelitian tersebut, maka dipabrikasi sistem pengontrol pendistribusian air PDAM dengan mekanisme prabayar melalui sistem pengontrolan berbasis mikrokontroler untuk pengaliran air ke ke konsumen sesuai kuota air terbeli dan pemantauan kondisi dimaksud melalui Wi-Fimodule

\section{Metode Penelitian}

Sejumlah piranti elektronika dibutuhkan pada penelitian ini, yaitu Ethernet shield, ESP8266, solenoid valve, sensor waterflow, sensor ultrasonik, LCD, dan buzzer. Tahapan-tahapan untuk pencapaian setiap sasaran penelitian pada metode penelitian dibuat dalam bentuk diagram alir (flowcart). Diagram alir metode penelitian, seperti ditunjukkan pada Gambar 2. 

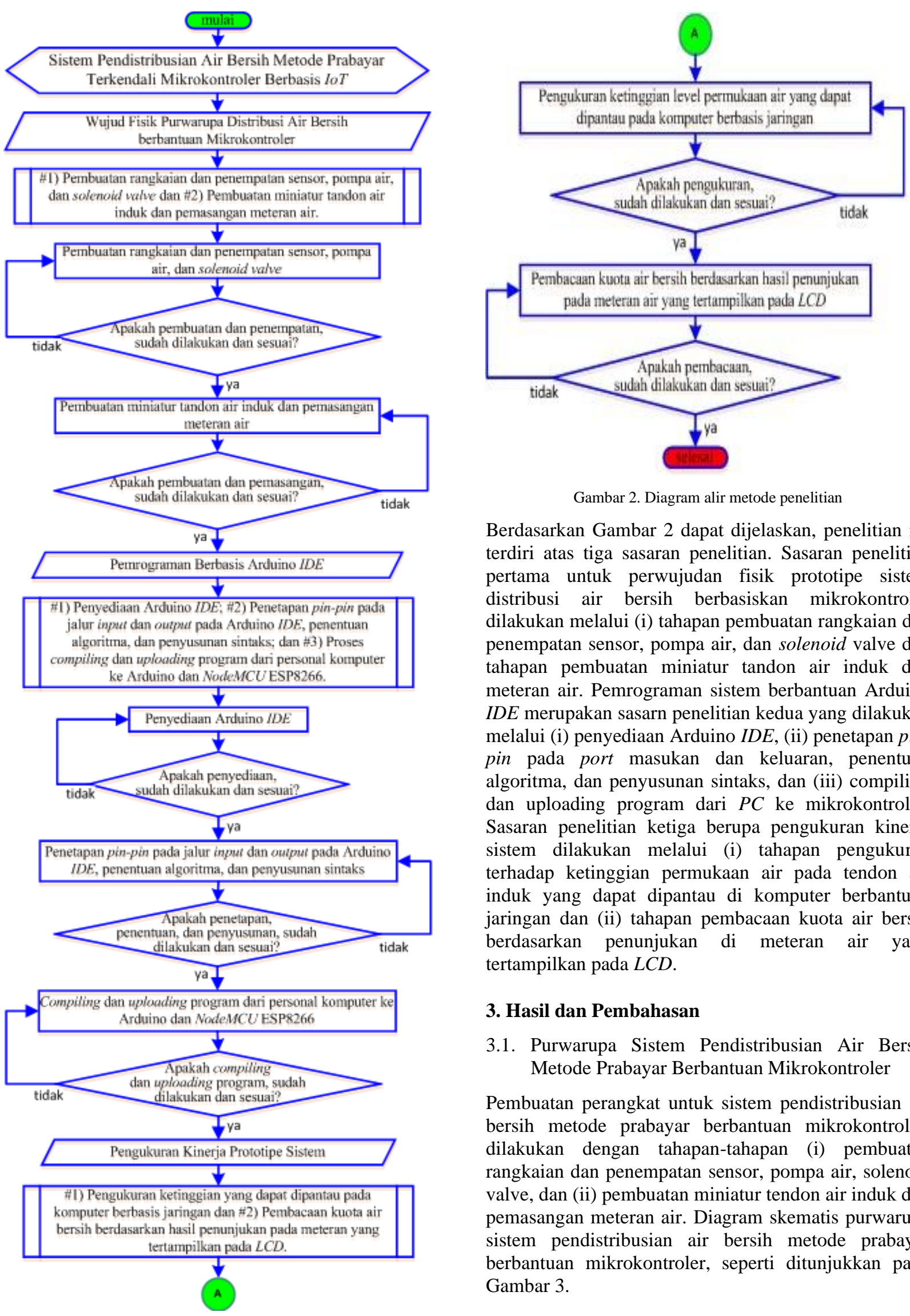

Gambar 2. Diagram alir metode penelitian

Berdasarkan Gambar 2 dapat dijelaskan, penelitian ini terdiri atas tiga sasaran penelitian. Sasaran penelitian pertama untuk perwujudan fisik prototipe sistem distribusi air bersih berbasiskan mikrokontroler dilakukan melalui (i) tahapan pembuatan rangkaian dan penempatan sensor, pompa air, dan solenoid valve dan tahapan pembuatan miniatur tandon air induk dan meteran air. Pemrograman sistem berbantuan Arduino $I D E$ merupakan sasarn penelitian kedua yang dilakukan melalui (i) penyediaan Arduino IDE, (ii) penetapan pinpin pada port masukan dan keluaran, penentuan algoritma, dan penyusunan sintaks, dan (iii) compiling dan uploading program dari $P C$ ke mikrokontroler. Sasaran penelitian ketiga berupa pengukuran kinerja sistem dilakukan melalui (i) tahapan pengukuran terhadap ketinggian permukaan air pada tendon air induk yang dapat dipantau di komputer berbantuan jaringan dan (ii) tahapan pembacaan kuota air bersih berdasarkan penunjukan di meteran air yang tertampilkan pada $L C D$.

\section{Hasil dan Pembahasan}

3.1. Purwarupa Sistem Pendistribusian Air Bersih Metode Prabayar Berbantuan Mikrokontroler

Pembuatan perangkat untuk sistem pendistribusian air bersih metode prabayar berbantuan mikrokontroler, dilakukan dengan tahapan-tahapan (i) pembuatan rangkaian dan penempatan sensor, pompa air, solenoid valve, dan (ii) pembuatan miniatur tendon air induk dan pemasangan meteran air. Diagram skematis purwarupa sistem pendistribusian air bersih metode prabayar berbantuan mikrokontroler, seperti ditunjukkan pada Gambar 3.

DOI: https://doi.org/10.29207/resti.v5i6.3485

Lisensi: Creative Commons Attribution 4.0 International (CC BY 4.0) 


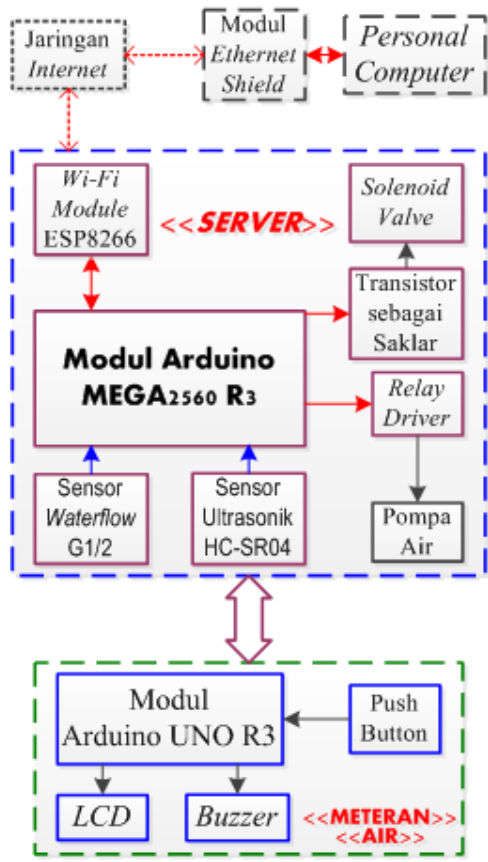

Gambar 3. Diagram skematis purwarupa sistem pendistribusian air bersih metode prabayar berbantuan mikrokontroler ush button diterima oleh modul Arduino UNO R3 yang difungsikan sebagai meteran air tipe digital yang dikirim ke modul Arduino MEGA2560 R3 untuk pengaktifan pompa air dan solenoid valve. Untuk kondisi ketika kuota air habis, secara otomatis selenoid valve "menutup" dan pelanggan harus lakukan pengadaan kuota air kembali untuk pembukaan solenoid valve tersebut. Penghitungan volume air yang masuk ke rumah pelanggan digunakan sensor waterflow G1/2, data sensor dikirimkan ke modul Arduino UNO R3 dan ditampilkan pada $L C D$ dan smartphone sebagai pembacaan kuota air. Sensor kirim logika $L O W$ pada modul Arduino MEGA2560 untuk penutupan solenoid valve, jika kuota air habis dan pengaktifan buzzer untuk pemberitahuan kepada pelanggan.

Sensor ultrasonik HC-SR04 digunakan untuk pembacaan ketinggian permukaan air. Penampungan air pada tendon air induk tidak boleh di level lebih kecil dari $50 \%$ dan lebih besar dari $90 \%$ dari ketinggian galon, dan harus pada level $80 \%$ hingga $95 \%$. Level air berada dibawah $50 \%$ pompa air cepat menjadi panas dan berpotensi cepat rusak. Informasi ketinggian permukaan air dikirimkan dari modul Arduino MEGA2560 R3 dan ditampilkan pada halaman website, jika level air kecil Berdasarkan Gambar 3 dapat dijelaskan, bahwa 50\% ditampilkan informasi "Air Digalon Induk Tinggal perangkat terkendali oleh dua modul Arduino. Modul Sedikit, Segera Ditambahkan Kembali Sebelum Habis". Arduino MEGA2560 R3 difungsikan sebagai server Untuk kondisi level air besar dari 90\% ditampilkan untuk pemasukan air bersih sesuai kode rumah warga informasi "Air di Galon Hampir Penuh". Rangkaian melalui jaringan Lokal Area Network (LAN) ke solenoid keseluruhan pengawatan terintegrasi prototipe sistem valve yang difungsikan sebagai kran otomatis. Pompa air pendistribusian air PDAM metode prabayar berbasis IoT dan solenoid valve diaktifkan dengan penekanan push ditunjukkan pada Gambar 4.

button yang terdapat di meteran air rumah warga. Data

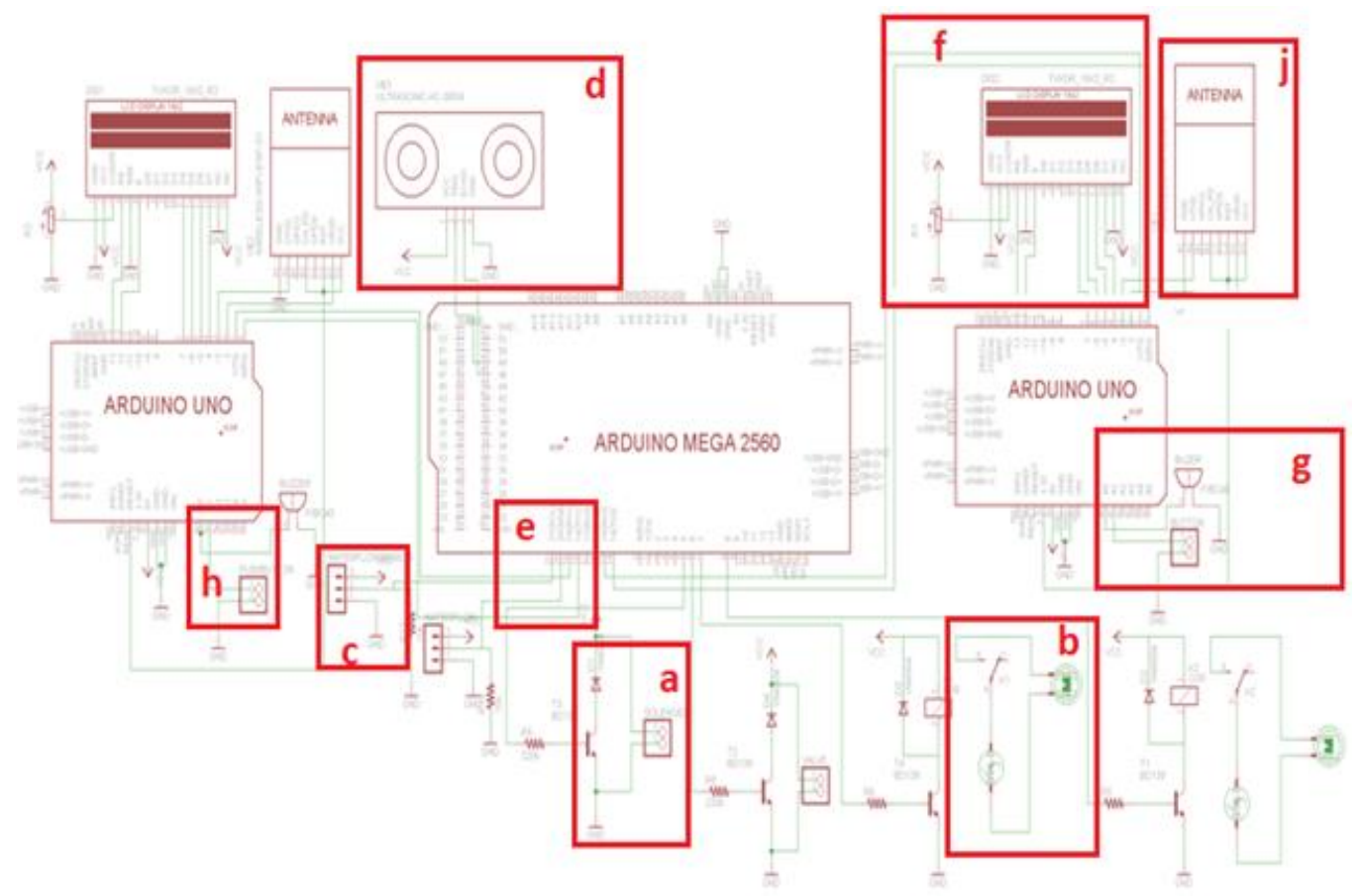

Gambar 4. Pengawatan terintegrasi prototipe sistem pendistribusian air PDAM metode prabayar berbasis IoT

DOI: https://doi.org/10.29207/resti.v5i6.3485

Lisensi: Creative Commons Attribution 4.0 International (CC BY 4.0) 
\#A) Rangkaian dan penempatan sensor, pompa air, dan solenoid valve

Tahapan ini dilakukan pembuatan rangkaian elektronika yang terdiri atas rangkaian (a) transistor switching, (b) relay driver, (c) sensor waterflow G1/2, (d) sensor ultrasonik HC-SR04, (e) komunikasi serial antara Arduino UNO R3 dan MEGA2560 R3, (f) LCD 2x16, (g) alarm peringatan kuota telah habis (Pelanggan), (h) kode pengaktifan kuota air, (i) Ethernet Shield ke Arduino MEGA2560 R3, dan (j) NodeMCU ESP8266.

\section{\#a) Rangkaian transistor switching}

Rangkaian transistor switching digunakan untuk pengendalian solenoid valve $12 \mathrm{Vdc}$ yang dihubungkan ke pin 6 dan pin 5 pada modul Arduino MEGA2560 R3. Saat pin pada modul Arduino diberikan logika $H I G H$, maka solenoid valve terbuka(nornally open). Rangkaian Rangkaian komunikasi serial difungsikan untuk LED dihubungkan ke transistor switching sebagai mengirimkan data sensor water flow G1/2 pada arduino indikator aktif atau tidak aktif solenoid valve. mega 2560 sebagai server ke arduino uno R3 untuk Keterhubungan pin Arduino MEGA2560 R3 ke solenoid valve dan $L E D$, seperti ditunjukkan pada Tabel 1.

Tabel 1. Keterhubungan pin Arduino MEGA2560 R3 ke solenoid valve dan $L E D$

\begin{tabular}{ccccc}
\hline $\begin{array}{c}\text { Pin } \\
\text { Arduino } \\
\text { MEGA2560 }\end{array}$ & Komponen & $\begin{array}{c}\text { Solenoid } \\
\text { Valve, } \\
\mathbf{1 2} \text { Vdc }\end{array}$ & LED & $\begin{array}{c}\text { Reteranganard } \\
\text { dit }\end{array}$ \\
\hline 5 & $\begin{array}{c}\text { Transistor } \\
\text { switching }\end{array}$ & $\begin{array}{c}\text { Terbuka } \\
\text { (Aktif) }\end{array}$ & ON & $\begin{array}{c}\text { solenoid } \\
\text { valve, untuk } \\
\text { rumah 1 } \\
\text { solenoid } \\
\text { valve, untuk } \\
\text { rumah 2 }\end{array}$ \\
\hline
\end{tabular}

\#b) Rangkaian relay driver

Rangkaian relay driver digunakan untuk pengendalian kondisi ON/OFF pompa air $220 \mathrm{~V}$ ac yang dihubungkan ke pin 7 dan pin 8 pada modul Arduino MEGA2560 R3. Saat pin pada Arduino diberikan logika $H I G H$,pompa diaktifkan. Indikator pompa air telah ON/OFF ditandai olehnyala/padam dari $L E D$.

\#c) Rangkaian sensor waterflow G1/2, sensor ultrasonik HC-SR04, dan $L C D$

Rangkaian sensor water flow G1/2 difungsikan untuk
penghitungan jumlah debit air dihubungkan ke pin 20 dan pin 21 pada modul Arduino MEGA2560 R3. Pin untuk trigger sensor ultrasonik HC-SR04 dihubungkan ke pin 48, sedangkan pin echo dihubungkan ke pin 46 pada modul Arduino MEGA2560 R3. Rangkaian LCD digunakan untuk penampilan kuota pembelian dan volume air yang dihubungkan ke modul Arduino UNO R3. Keterhubungan antar pin pada modul Arduino, sensor, dan $L C D$, seperti ditunjukkan pada Tabel 2.
Tabel 2. Keterhubungan antar pin pada modul Arduino, sensor, dan $L C D$

\begin{tabular}{ccc}
\hline Komponen & Pin & Keterangan \\
\hline & 20 & \\
& (Arduino & perhitungan debit air \\
untuk rumah 1 & \\
Sensor Waterflow & R3) & \\
G1/2 & 21 & \\
& (Arduino & perhitungan debit air \\
& MEGA2560 & untuk rumah 2 \\
Sensor Ultrasonik & Recho (46) & input \\
HC-SR04 & Trigger (48) & output \\
& $2,3,5,11,12$ & Tampilan Kuota Air \\
LCD & (Arduino & \\
& UNO R3) & \\
\hline
\end{tabular}

\#d) Rangkaian komunikasi serial, Ethernet Shield dan NodeMCU ESP8266. pada LCD Ethernet shield difungsikan untuk komunikasi arduino mega2560 dengan jaringan LAN dihubungkan pada pin 10,11,12 dan 13 arduino. Rangkaian ESP8266 digunakan untuk untuk komunikasi rduino uno dengan jaringan wireless. Penempatan pin ditunjukkan pada tabel 3 dan tabel 4 .

\begin{tabular}{cc} 
Tabel 3.Penenpatan Pin Arduino pada Ethernet Shield \\
\hline $\begin{array}{c}\text { Pin pada Arduino } \\
\text { MEGA2560 }\end{array}$ & $\begin{array}{c}\text { Pin pada Ethernet } \\
\text { Shield }\end{array}$ \\
\hline 10 & SS \\
11 & MOSI \\
12 & MISO \\
13 & SCK
\end{tabular}

Tabel 4.Penepatan keterhubungan pin Arduino pada ESP8266

\begin{tabular}{cc}
\hline Pin Arduino Uno & Pin ESP8266 \\
\hline 10 & VCC \\
$3.3 \mathrm{~V}$ & RST \\
$3.3 \mathrm{~V}$ & CH_PD \\
$3.3 \mathrm{~V}$ & GND \\
GND & URXD \\
2 & UTXD \\
3 & VCC \\
\hline
\end{tabular}

\#B) Miniatur tandon air induk dan meteran air Alat yang dibuat pada sistem ini menggunakan 1 buah galon induk berukuran 19 liter air, besi L digunakan untuk kedudukan galon dan pipa. Untuk rangkaian sistem elektronika ditempatkan di dalam kotak (boks). Purwarupa sistem pendistribusian air bersih metode prabayar berbasis IoT, seperti ditunjukkan pada Gambar 5 .

DOI: https://doi.org/10.29207/resti.v5i6.3485

Lisensi: Creative Commons Attribution 4.0 International (CC BY 4.0) 


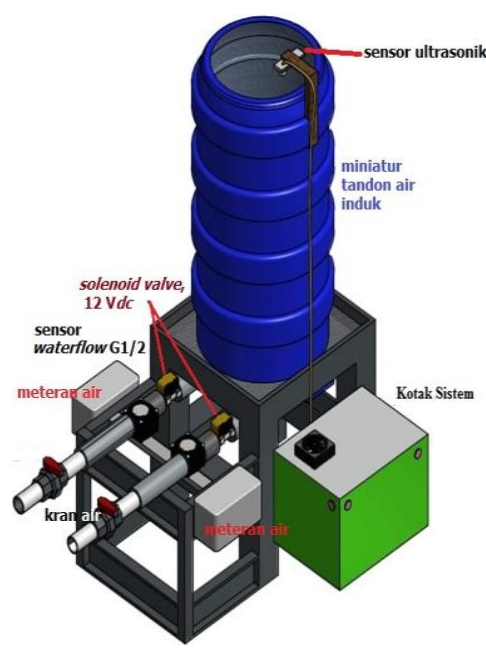

Gambar 5. Purwarupa sistem pendistribusian air bersih metode prabayar berbasis $I o T$

\subsection{Pemrograman Sistem}

Sejumlah tahapan dilakukan pada pemrograman sistem, yaitu (i) penyediaan Arduino IDE, (ii) penetapan pin-pin pada port masukan, keluaran, dan penetapan algoritma, dan (iii) pengunggahan program dari $P C$ ke modul mikrokontroler. Arduino IDE versi 1.8.13 digunakan untuk pemrograman pada penelitian ini. Tahapan pada proses penyediaan Arduino IDE yaitu, (i) pengunduhan Arduino IDE, (ii) proses pemasangan (penginstalan), dan (iii) pemilihan tipe mikrokontroler.

Penetapan pin-pin pada jalur input/output dan penentuan algoritma, dilakukan untuk kemudahan dalam pemograman. Penetapan pin-pin pada port masukan dan keluaran, seperti ditunjukkan pada Tabel 5.

Tabel 5. Penenpatan pin-pin pada port masukan dan keluaran

\begin{tabular}{|c|c|c|c|}
\hline Mikrokontroler & Port dan Pin & Komponen & Keterangan \\
\hline \multirow{6}{*}{$\begin{array}{c}\text { Arduino } \\
\text { MEGA2560 R3 }\end{array}$} & $\begin{array}{l}\text { PE3 - Digital } \\
\quad \text { pin } 5\end{array}$ & $\begin{array}{l}\text { Transistor } \\
\text { switching }\end{array}$ & output \\
\hline & $\begin{array}{l}\text { PE4 - Digital } \\
\quad \text { pin } 6\end{array}$ & $\begin{array}{l}\text { Transistor } \\
\text { switching }\end{array}$ & output \\
\hline & $\begin{array}{l}\text { PB1 - Digital } \\
\quad \text { pin } 20\end{array}$ & $\begin{array}{c}\text { Sensor } \\
\text { Waterflow } \\
\text { G1/2 }\end{array}$ & input \\
\hline & $\begin{array}{l}\text { PB2 - Digital } \\
\quad \text { pin } 21\end{array}$ & $\begin{array}{c}\text { Sensor } \\
\text { Waterflow } \\
\text { G1/2 }\end{array}$ & input \\
\hline & $\begin{array}{l}\text { PD3 - Digital } \\
\text { pin } 46\end{array}$ & $\begin{array}{l}\text { Sensor } \\
\text { Ultrasonik } \\
\text { HC-SR04 }\end{array}$ & input \\
\hline & $\begin{array}{l}\text { PD5 - Digital } \\
\quad \text { pin } 48\end{array}$ & $\begin{array}{c}\text { Sensor } \\
\text { Ultrasonik } \\
\text { HC-SR04 }\end{array}$ & output \\
\hline \multirow{2}{*}{$\begin{array}{l}\text { Arduino } \\
\text { UNO R3 }\end{array}$} & $\begin{array}{l}\text { Digital Pin } 6 \\
\text { dan } 13\end{array}$ & Buzzer & output \\
\hline & $\begin{array}{c}\text { Digital Pin 2, 3, } \\
5,11 \text {, dan } 12\end{array}$ & $L C D$ & output \\
\hline
\end{tabular}

Setelah penetapan pin-pin pada port masukan/keluaran, dilanjutkan dengan penetapan algoritma pemrograman.

DOI: https://doi.org/10.29207/resti.v5i6.3485
Algoritma pemrograman sistem pendistribusian air bersih metode prabayar terkendali mikrokontroler berbasis $I o T$, seperti ditunjukkan pada Gambar 6 .

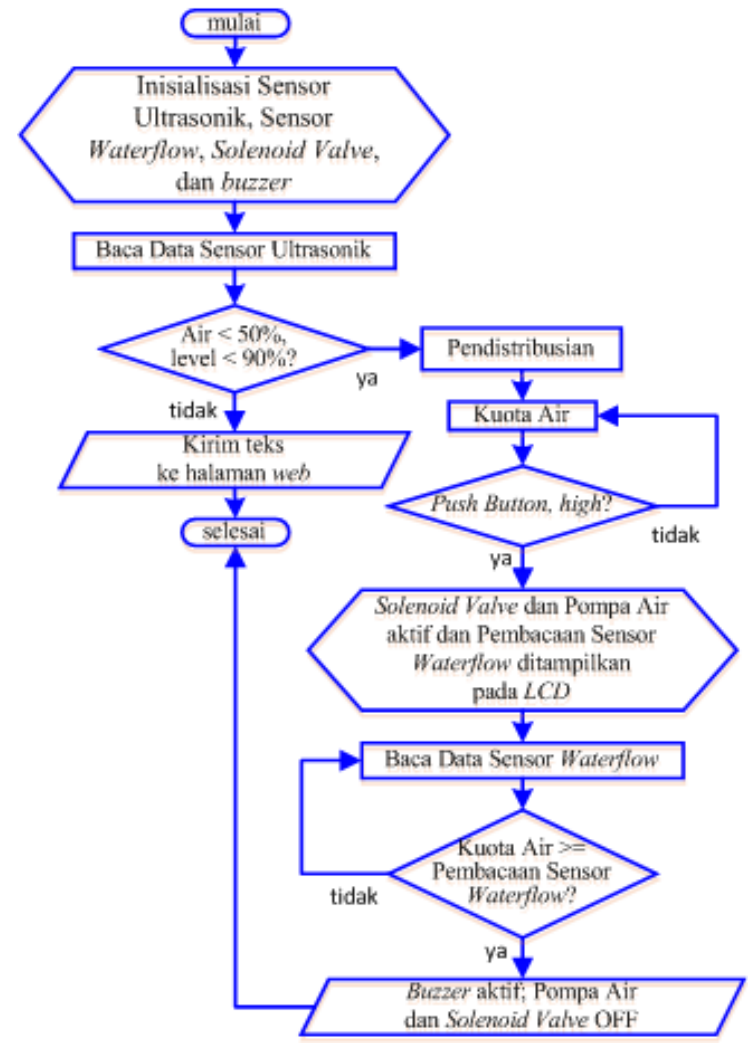

Gambar 6. Algoritma pemrograman sistem pendistribusian air bersih metode prabayar terkendali mikrokontroler berbasis $I o T$

Berdasarkan Gambar 6 dapat dijelaskan, bahwa sensor pembaca level air di tandon air induk dengan level air 90\% air didistribusikan dan tertampilkan halaman web untuk pengisian kuota air. Harga air dibuat sesuai harga sebenarnya pada PDAM. Biaya pemakaian air per meter kubik pada prototipe dikonversi ke satuan liter, seperti ditunjukkan pada tabel 6 .

Tabel 6. Biaya pemakaian air per meter kubik pada prototipe dikonversi ke satuan liter

\begin{tabular}{|c|c|c|c|c|c|}
\hline $\begin{array}{l}\text { Jenis } \\
\text { Tarif }\end{array}$ & $\begin{array}{c}\text { Harga } \\
\text { 0-10 m } \\
\text { (Rp.) }\end{array}$ & $\begin{array}{c}\text { Dana } \\
\text { Meter } \\
\text { (Rp.) }\end{array}$ & $\begin{array}{c}\text { Biaya } \\
\text { Admin. } \\
\text { (Rp.) }\end{array}$ & $\begin{array}{c}\text { Retribusi } \\
\text { Sampah } \\
\text { (Rp.) }\end{array}$ & $\begin{array}{c}\text { Total } \\
\left(\mathbf{R p} . / \mathbf{m}^{3}\right)\end{array}$ \\
\hline $2 c$ & $2.185,00$ & $4.500,00$ & $3.000,00$ & $5.000,00$ & $15.000,00$ \\
\hline
\end{tabular}

Berdasarkan Tabel 6 dapat dijelaskan, bahwa kategori harga air, meliputi (a) Rp.15.000,00 untuk satu liter air, (b) Rp.17.000,00 untuk dua liter air, dan (c) Rp.19.000,00 untuk tiga liter air. Tahapan lanjutan dilakukan pemrograman berbantuan Arduino IDE yang dimulai dari akuisisi data, pengontrolan, dan komunikasi data. Listing program untuk keterhubungan sensor

Lisensi: Creative Commons Attribution 4.0 International (CC BY 4.0) 
ultrasonik dan waterflow melalui ESP8266, seperti dikonversi menjadi file .hex dan diunggah ke ditunjukkan pada Gambar 7.

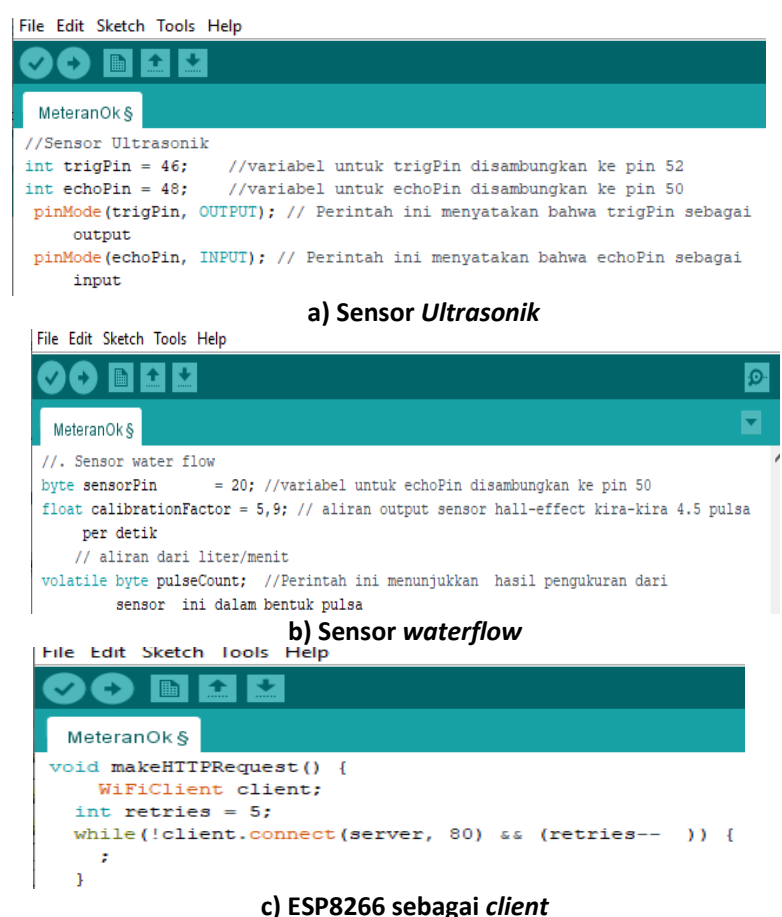

Gambar 7. Listing program untuk keterhubungan sensor ultrasonic dan waterflow melalui ESP8266 pemrograman, dilanjutkan tahapan compiling dan uploading.

Sintaks program kemudian di-compile untuk dikonversi menjadi file .hex. Tampilan proses compiling, seperti ditunjukkan pada Gambar 8.

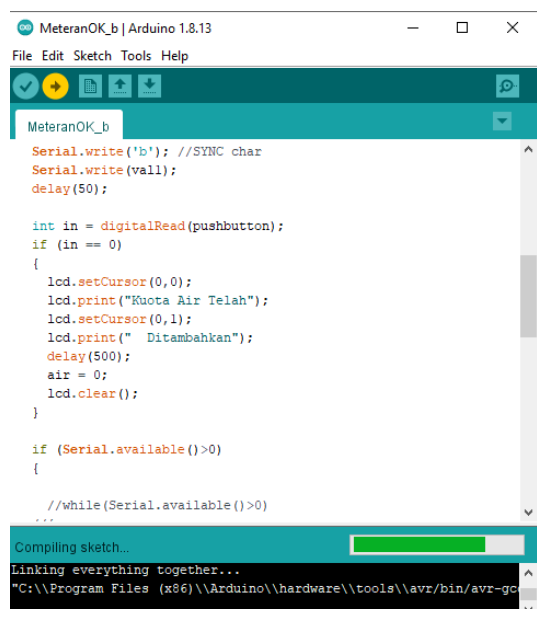

Gambar 8. Tampilan proses compiling

Berpedoman kepada hasil pada Gambar 8, maka dilanjutkan Sintaks program kemudian di-compile untuk mikrokontroler dari $P C$ berbantuan kabel USB. Tampilan diagram skematis proses uploading sintaks program dari $P C$ ke dalam mikrokontroler, seperti ditunjukkan pada Gambar 9.

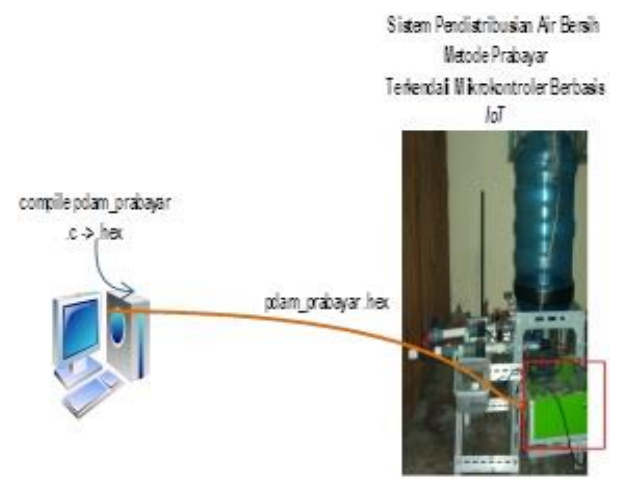

Gambar 9. Tampilan diagram skematis proses uploading sintaks program dari $P C$ ke dalam mikrokontroler

\subsection{Pengukuran Kinerja Sistem}

Pengukuran kinerja sistem dilakukan pada 2 (dua) kondisi, yaitu (1) ketinggian air bersih pada tandon air induk yang dapat dipantau di komputer berbasis jaringan dan (2) tampilan pembacaan kuota air bersih pada Liquid Crystal Display $(L C D)$ yang terdapat di meteran air.

1) Pengukuran ketinggian permukaan air bersih yang dapat dipantau di komputer berbasis jaringan

Pengukuran dilakukan dengan tahapan, yaitu (i) pengukuran pada rangkaian transistor switching, (ii) pengukuran pada rangkaian relay driver, (iii) pengukuran level permukaan air dengan sensor ultrasonik HC-SR04, (iv) pengukuran rangkaian sensor water flow g1/2

1a) Pengukuran pada rangkaian transistor switching

Pengukuran dilakukan terhadap transistor yang digunakan sebagai saklar untuk pengaktifkan solenoid valve berbantuan koil $12 \mathrm{Vdc}$. Nilai tegangan hasil pengukuran pada transistor switching, seperti ditunjukkan pada Tabel 7.

Tabel 7. Nilai tegangan hasil pengukuran pada transistor switching

\begin{tabular}{|c|c|c|c|c|}
\hline \multicolumn{4}{|c|}{ Pengukuran } & \multirow{2}{*}{$\begin{array}{c}\text { Kondisi } \\
\text { Transistor }\end{array}$} \\
\hline $\mathrm{V}_{\text {in }}$ & $\mathrm{V}_{\mathrm{BE}}$ & $\mathrm{V}_{\mathrm{CE}}$ & $\mathrm{V}_{\mathrm{CC}}$ & \\
\hline $4,5 \mathrm{~V}$ & $0,72 \mathrm{~V}$ & $0,01 \mathrm{~V}$ & $11,2 \mathrm{~V}$ & Saturasi \\
\hline $0,01 \mathrm{~V}$ & $0,01 \mathrm{~V}$ & $11,2 \mathrm{~V}$ & $0 \mathrm{~V}$ & cut-off \\
\hline
\end{tabular}

Berdasarkan pada Tabel 7 didapatkan hasil saat pin arduino berlogika $L O W$ tegangan terukur sebesar $0,01 \mathrm{~V}$ yang merupakan pencatu transistor. Saat pin berlogika HIGH transistor menjadi terkondoksi saturasi, sehingga tegangan pada $\mathrm{V}_{\mathrm{BE}}$ sebesar $0,72 \mathrm{~V}$ dan pada $\mathrm{V}_{\mathrm{CE}}$ sebesar 0,01 V. Kondisi tersebut sebagai pemicu kondisi

DOI: https://doi.org/10.29207/resti.v5i6.3485

Lisensi: Creative Commons Attribution 4.0 International (CC BY 4.0) 
solenoid valve dalam keadaan terbuka, karena selenoid Pengukuran ketinggian permukaan air pada tandon air valve terhubung dengan $\mathrm{V}_{\mathrm{CC}}$ dan $\mathrm{V}_{\mathrm{CE}}$. Saat pin pada induk, seperti ditunjukkan pada Gambar 10.

Arduino berlogika $L O W$, transistor dalam keadaan cutoff, sehingga tegangan $\mathrm{V}_{\mathrm{BE}}$ terukur $0,01 \mathrm{~V}$ dan tegangan $\mathrm{V}_{\mathrm{CE}}$ menjadi bernilai sama dengan tegangan sumber $\mathrm{V}_{\mathrm{CC}}$ sebesar 11,24 V. Hal itu berakibat kepada konsisi solenoid valve kembali ke kondisi normal, karena tegangan pada $\mathrm{V}_{\mathrm{CE}}$ bernilai sama dengan $\mathrm{V}_{\mathrm{CC}}$.

1b) Pengukuran pada blok rangkaian relay driver untuk pompa air

Rangkaian relaydriver juga dengan rangkaian transistor switching untuk pengaktifan dan penonaktifan relai. Titik pengukuran sama dengan pengukuran untuk rangakaian transistor switching. Hasil pengukuran pada blok relay driver, seperti ditunjukkan pada Tabel 8.

Tabel 8. Hasil pengukuran pada blok relay driver

\begin{tabular}{ccccc}
\hline \multicolumn{4}{c}{ Pengukuran } & Posisi \\
\cline { 1 - 4 } Vin & $\mathrm{V}_{\mathrm{BE}}$ & $\mathrm{V}_{\mathrm{CE}}$ & $\mathrm{V} a c$ & Relai \\
\hline $4,44 \mathrm{~V}$ & $0,7 \mathrm{~V}$ & $0,03 \mathrm{~V}$ & $210 \mathrm{~V}$ & $\mathrm{ON}$ \\
$0,01 \mathrm{~V}$ & $0,01 \mathrm{~V}$ & $11,2 \mathrm{~V}$ & $0 \mathrm{~V}$ & OFF \\
\hline
\end{tabular}

Berdasarkan Tabel 8 dapat dijelaskan, bahwa rangkaian relaydriver dengan rangkaian transistor switching yang digunakan untuk pengoperasian solenoid valve, saturasi saat tegangan $\mathrm{V}_{\mathrm{BE}} 0,71 \mathrm{~V}$ dan cut-off saat tegangan $\mathrm{V}_{\mathrm{BE}}$ $0,01 \mathrm{~V}$, sesuai dengan bahan transistor dari silicon, yaitu tegangan saat saturasi pada $\mathrm{V}_{\mathrm{BE}}$ bernilai $0,7 \mathrm{~V}$ dan saat cut-off tegangan $\mathrm{V}_{\mathrm{BE}}$ bernilai lebih kecil dari $0,7 \mathrm{~V}$. Saat transistor dalam keadaan saturasi, keluaran di pin modul Arduino dengan pasokan tegangan sebesar 4,44 V, agar relai aktif dan pompa air beroperasi, dan tegangan $\mathrm{V}_{\mathrm{CE}}$ menjadi $0,03 \mathrm{~V}$. Tegangan sebesar $4,44 \mathrm{~V}$ dari pin Arduino merupakan tegangan keluaran saat berlogika HIGH, berdasarkan datasheetArduino tegangan output dari masing-masing pin pada port keluaran modul Arduino sebesar $5 \mathrm{~V}$, tetapi tegangan terukur sebesar 4,44 V. Hal itu disebabkan oleh ketidakstabilan nilai masukan yang digunakan saat proses pengukuran. Nilai tegangan tersebut tidak berpengaruh terhadap operasi relai, karena nilai tegangan $V_{\mathrm{BE}}$ sudah tercapai pada 0,7 $\mathrm{V}$, sebagaimana hasil penelitian Baszynski-Pirog dan Perkasa, et al.

1c) Pengukuran pada modul sensor ultrasonik HC-SR04 dan Arduino MEGA2560 R3

Pengukuran dilakukan pada modul sensor ultrasonik HC-SR04 untuk penunjukan kinerja sensor pada saat digunakan untuk pengiriman data ketinggian permukaan air pada tandon air induk dalam satuan centimeter kemudian dikalkulasikan menjadi ketinggian permukaan air pada mikrokontroler. Pengukuran dilakukan pada sensor dengan pengukuran ketinggian permukaan air yang terbaca oleh sensor ultrasonik $\mathrm{HC}$ SR04 dan dibandingkan terhadap mistar ukur.
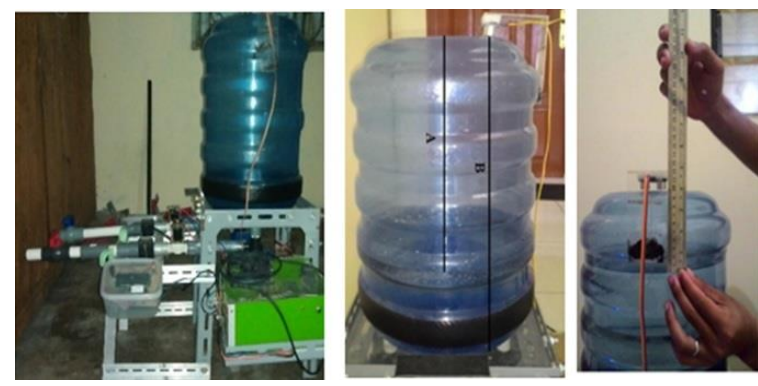

Gambar 10. Pengukuran ketinggian permukaan air pada tandon air induk

Berdasarkan Gambar 10 dapat dijelaskan, bahwa data terukur oleh sensor diubah menjadi ketinggian permukaan air dalam satuan persen. Ekivalensi data terukur pada ketinggian permukaan air, seperti ditunjukkan Tabel 9.

Tabel 9. Ekivalensi data terukur pada ketinggian permukaan air

\begin{tabular}{cccc}
\hline $\begin{array}{c}\text { Jarak } \\
\text { Terbaca } \\
\text { Sensor } \\
\begin{array}{c}\text { Ultrasonik } \\
(\mathbf{c m})\end{array}\end{array}$ & $\begin{array}{c}\text { Jarak } \\
\text { Sebenarnya } \\
(\mathbf{c m})\end{array}$ & $\begin{array}{c}\text { Error } \\
\text { Pengukuran } \\
\text { Jarak } \\
(\boldsymbol{\%})\end{array}$ & $\begin{array}{c}\text { Ketinggian } \\
\text { Permukaan } \\
\text { Air } \\
(\%)\end{array}$ \\
\hline 2 & 1 & -100 & 95 \\
2 & 2,5 & 20 & 95 \\
4 & 4,5 & 11,11 & 95 \\
6 & 6 & 0 & 84 \\
8 & 8 & 0 & 84 \\
10 & 10 & 0 & 73 \\
12 & 12 & 0 & 67 \\
14 & 14 & 0 & 62 \\
18 & 18 & 0 & 50 \\
\hline
\end{tabular}

Berdasarkan Tabel 9 dapat dibuat kurva hubungan antara persen ketinggian permukaan air dan ketinggian permukaan air terdeteksi oleh sensor ultrasonik HC5R04. Kurva hubungan antara persen persen ketinggian permukaan air dan hasil pendeteksian sensor ultrasonik, seperti ditunjukkan pada Gambar 11.

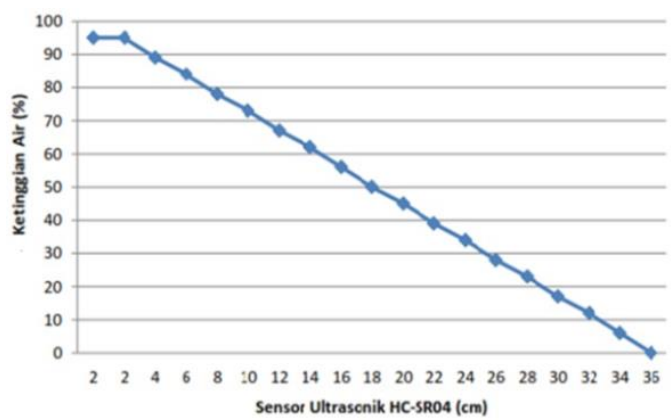

Gambar 11. Kurva hubungan antara persen ketinggian permukaan air dan hasil pendeteksian sensor ultrasonik

Sensor ultrasonik beroperasi berdasarkan prinsip gelombang ultrasonik. Jarak terukur berdasarkan hasil 
pendeteksian sensor ultrasonik, diperoleh dengan pen- dengan penelitian Akbar dan Rachmat. Kenaikan triger-an pada pin "trigger", sehingga dipancarkan ketinggian permukaan air dengan jarak pada sensor gelombang ultrasonik dan dipantulkan oleh objek terdapat perbedaan nilai, yaitu rentang jarak sensor per permukaan air dan diterima melalui pin "echo" pada $2 \mathrm{~cm}$, sedangkan rentang kenaikan ketinggian sensor ultasonik. Selisih waktu antara pemancaran permukaan air lima dan enam cm. gelombang ultrasonik dan penerimaan, merupakan pulsa dan dikonversikan oleh Arduino untuk dihasilkan data

\section{1d) Pengukutan rangkaian sensor waterflow G1/2}

dari jumlah kapasitas air. Persamaan untuk Pengukuran dilakukan untuk penunjukan kinerja sensor pemrograman berupa konversi pulsa diterima oleh waterflow G1/2 dalam pengukuran debit air. Tegangan "echo", adalah $\mathrm{cm}=$ duration $* 0,034 / 2$.

Data error pada Tabel 9 disebabkan oleh bidang pantul dari sinyal transmitter ke receiver berbeda dengan data lainnya. Pantulan yang didapatkan Tabung penampungan air tidak selindris, sehingga saat sinyal transmitter bidang tersebut, pantulan diperoleh bukan dari permukaan air, melainkan dari dinding berbentuk cekung, sehingga berdasarkan cara operasi sensor ultrasonik dengan selisih waktu sinyal transmitter dan sinyal receiver menjadi lebih singkat. Saat lama waktu tersebut dikonversikan ke jarak, maka nilai diperoleh menjadi lebih kecil dibandingkan dengan nilai dari alat ukur. Waktu lebih singkat merupakan penyebab data jarak yang diperoleh menjadi lebih kecil. Error tidak terjadi saat pembacaan di tengah tabung, hal ini sebagai bukti, bahwa lengkungan pada bagian bawah dan atas berpengaruh terhadap hasil pembacaan.

Saat pembacaan sensor tetap sebesar dua $\mathrm{cm}$ padahal jarak yang diperoleh dengan alat ukur sudah kecil dari dua $\mathrm{cm}$. Hal itu disebabkan oleh kemampuan sensor ultrasonik sesuai datasheet perihal penjelasan pembacaan jarak minimal sensor ultrasonik sebesar dua $\mathrm{cm}$, setelah sensor tidak mampu lagi dalam pembacaan. Nilai error diperoleh berdasarkan hasil pembacaan pada bawah tabung, sehingga sebagai bukti, bahwa semakin cekung suatu bidang, maka pantulan sinyal menjadi lebih cepat. Bidang cekung menjadi linear kembali, melalui penunjukan nilai error menjadi semakin berkurang. Nilai error terbesar bernilai $100 \%$, saat sensor berkemampuan minimal.

Ketinggian permukaan air merupakan kebalikan dari jarak terukur oleh sensor. Jarak terukur oleh sensor semakin kecil, maka ketinggian permukaan air semakin besar, begitu juga kondisi sebaliknya. Nilai tersebut sebagai penanda, bahwa jika ketinggian permukaan air semakin dekat ke sensor ultrasonik yang dipasang pada bagian atas tandon air induk, maka jarak air terukur semakin dekat dengan sensor atau permukaan air dalam tandon air induk semakin tinggi. Ketinggian permukaan air tidak dapat tercapai hingga $100 \%$, karena kinerja sensor dibatasi oleh pembacaan jarak permukaan air terbaca pada jarak minimal dua $\mathrm{cm}$ dari sensor ultrasonik. Ketinggian permukaan air hanya dapat terbaca pada nilai maksimal sebesar $95 \%$, hal ini sesuai keluaran sensor sebesar 3,5-3,9 V saat dialiri air. Stopwatch digunakan untuk penunjukan waktu yang dibutuhkan dalam pencapaian kuota peng-input-an. Kuota terdistribusikan ke rumah-rumah dengan pilihan satu, dua, dan tiga liter. Hasil pengukuran sensor waterflow G1/2, seperti ditunjukkan pada Tabel 10 .

Tabel 10. Hasil pengukuran sensor waterflow G1/2

\begin{tabular}{|c|c|c|c|c|c|}
\hline $\begin{array}{l}\text { Input } \\
\text { (liter) }\end{array}$ & $\begin{array}{c}\text { Ketinggian } \\
\text { Air }\end{array}$ & $\begin{array}{c}\text { Waktu } \\
\text { (s) }\end{array}$ & $\begin{array}{c}\text { Gelas } \\
\text { Ukur } \\
(\mathrm{ml})\end{array}$ & $\begin{array}{c}\text { Debit } \\
\text { Air } \\
\text { Terukur } \\
\text { oleh } \\
\text { Sensor } \\
\text { (ml) } \\
\end{array}$ & $\begin{array}{c}\text { Error } \\
(\%)\end{array}$ \\
\hline \multirow{13}{*}{1 liter } & 95 & 12,66 & 1000 & 1034 & 3,29 \\
\hline & 90 & 12,55 & 970 & 994 & 2,41 \\
\hline & 87 & 12,51 & 1000 & 1022 & 2,15 \\
\hline & 82 & 12,45 & 1000 & 1025 & 2,44 \\
\hline & 76 & 13,06 & 1050 & 1067 & 1,59 \\
\hline & 71 & 12,72 & 1000 & 1043 & 4,12 \\
\hline & 65 & 13,06 & 1000 & 1058 & 5,48 \\
\hline & 60 & 13,26 & 950 & 1014 & 6,31 \\
\hline & 52 & 13,01 & 1000 & 1041 & 3,94 \\
\hline & 49 & 12,5 & 950 & 981 & 3,16 \\
\hline & 25 & 14,59 & 960 & 993 & 3,32 \\
\hline & 19 & 13,98 & 940 & 971 & 3,19 \\
\hline & 9 & 13,89 & 925 & 970 & 4,64 \\
\hline
\end{tabular}

Berdasarkan Tabel 10 dapat dijelaskan, bahwa saat ketinggian permukaan air mulai terjadi pengurangan, maka debit air yang dihasilkan berkurang dari kuota dan waktu yang dibutuhkan lebih dari rata-rata, sebesar satu detik. Persamaan untuk penghitungan laju aliran, yaitu

flowRate $=\frac{\left(\left(\frac{1000.0}{(\text { millis }()-\text { oldTime })}\right) * \text { pulseCount }\right)}{\text { CalibrationFactor }}$

Persamaan pada program juga dilakukan proses kalibrasi berdasarkan jumlah gelombang per detik per unit ukuran (liter/menit dalam kasus ini) dari sensor. Kalibarsi dilakukan bertujuan untuk perolehan jumlah pulsa per detik untuk ukuran per liter air sesuai dengan kecepatan air. Kalibrasi juga dilakukan dengan pemasukan nilai untuk perolehan hasil keluaran debit air sesuai dengan pembacaan dari kalkulasi program. Setelah diperoleh laju aliran dalam liter per menit, laju aliran diubah menjadi mililiter per detik dengan persamaan:

DOI: https://doi.org/10.29207/resti.v5i6.3485

Lisensi: Creative Commons Attribution 4.0 International (CC BY 4.0) 
flow $_{\text {milliLitres }}=\left(\frac{\text { flow }_{\text {rate }}}{60}\right) * 1.000$.

Berdasarkan persamaan tersebut kecepatan aliran dibagi enam puluh detik dikalikan dengan $1.000 \mathrm{ml}$. Setelah diperoleh data debit aliran dalam milliliter per detik, data tersebut selalu ditambahkan, sehingga diperoleh data pembacaan sensor waterflow dengan penggunaan sintaks program:

\section{tota1Mi11iLitres $+=$ flowMi11iLitres;}

Berdasarkan data tersebut, diperoleh nilai debit air dari laju kecepatan air. Sensor penghitung debit air yang digunakan tidak selalu sesuai, karena penambahan total milliliter air untuk pencapaian data yang diinginkan tidak akan selalu sama. Data dari sensor ditampilkan pada $L C D$. Tampilan data pada $L C D$, seperti yang ditunjukkan pada Gambar 12.

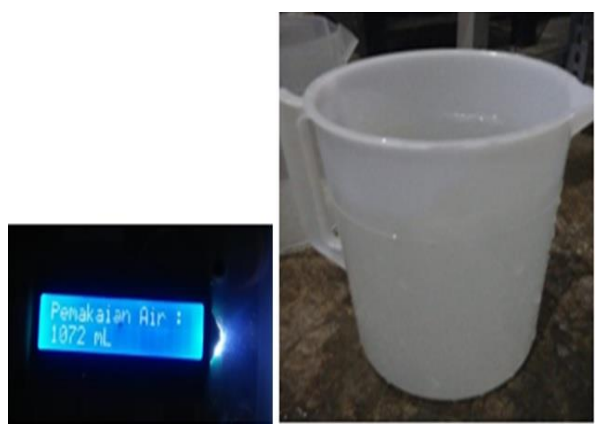

Gambar 12. Tampilan data pada $L C D$ untuk pemantauan air satu liter air

2) Tampilan pembacaan kuota air bersih

Tampilan ini bertujuan untuk pengukuran kinerja Ethernet shield dan ESP8266 pada purwarupa sistem pendistribusian air bersih. Ethernet shield difungsikan sebagai web server. Pemrograman jaringan berbasis HTML diprogram di modul Arduino. Pengukuran kinerja Arduino web server dilakukan dengan cara penghubungan web server ke $P C$, kemudian alamat $I P$ dari komputer dikonfigurasi untuk keterhubungan web server. Pengiriman data digunakan instruksi program if(Readstring.indexof //halaman yang dibaca Arduino). Tahapan setelah ini yang dilakukan Arduino, misalkan peng-input-an kuota air satu liter dan aksi berdasarkan program dengan pemberian data 1000 , maka data tersebut diolah oleh Arduino sesuai dengan program. Tampilan proses peng-input-an kuota air, ditunjukkan pada pada Gambar 13.

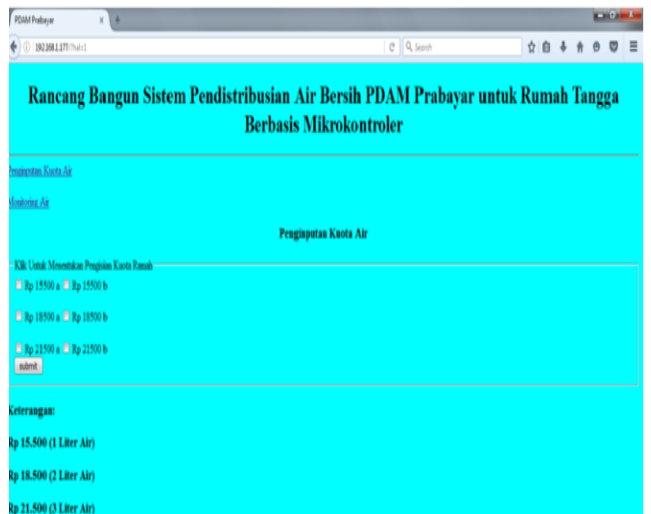

Gambar 13. Tampilan proses peng-input-an kuota air

Pengukuran kemampuan monitoring dengan ESP 8266 berbantuan aplikasi Thingspeak dilakukan untuk penunjukan ESP8266 yang terhubung ke Wi-Fi berfungsi untuk pemantauan debit air yang dialirkan. Untuk pengaksesan hasil pemantauan, ESP8266 dihubungkan dengan pin pada Arduino dengan tegangan 3,3V. Listing program untuk keterhubungan ESP8266 dengan jaringan Internet dan akun Thingspeak, seperti ditunjukkan Gambar 14.

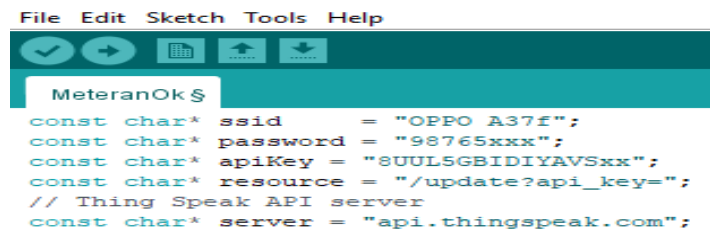

Gambar 14. Listing program untuk keterhubungan ESP8266 dengan jaringan Internet dan akun Thingspeak

Pengiriman data pemantauan pada aplikasi Thingspeak dikirim dari Arduino ke ESP8266 melalui keterhubungan pin RX dan TX pada ESP8266 ke pin pada modul Arduino. Tampilan volume kuota air pada smartphone, seperti ditunjukkan pada Gambar 15.

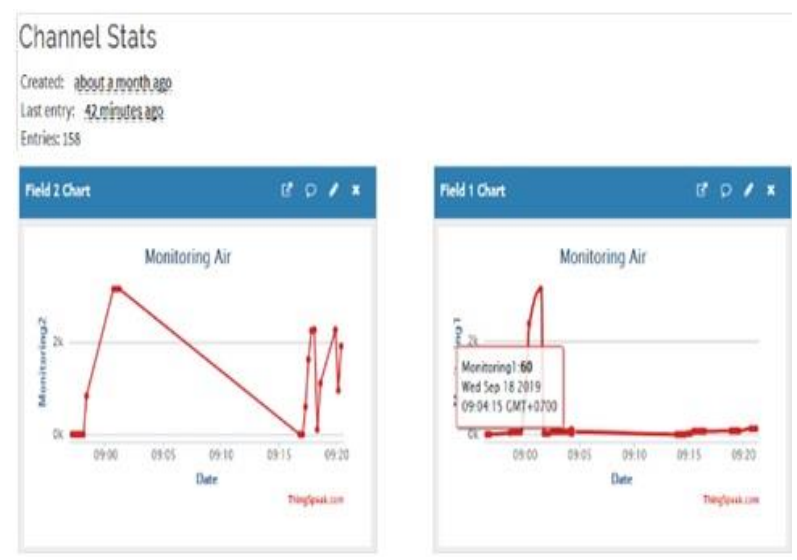

Gambar 15. Tampilan volume kuota air pada smartphone

DOI: https://doi.org/10.29207/resti.v5i6.3485

Lisensi: Creative Commons Attribution 4.0 International (CC BY 4.0) 


\section{Kesimpulan dan Saran}

Berdasarkan hasil dan pembahasan, maka dapat ditarik kesimpulan sesuai sasaran peneltian. Purwarupa dikendalikan oleh dua modul Arduino, yaitu Arduino MEGA2560 R3 difungsikan sebagai server untuk penginput-an air sesuai kode rumah warga melalui jaringan Lokal Area Network (LAN) dan Arduino UNO R3 difungsikan sebagai meteran pelanggan. Pembuatan purwarupa untuk pendistribusian air bersih metode prabayar terkendali mikrokontroler, dilakukan dengan tahapan-tahapan (i) pembuatan rangkaian dan penempatan sensor, pompa air, solenoid valve, dan (ii) pembuatan miniatur tandon air induk dan meteran air.

Pemograman sistem berbasis Arduino IDEdilakukan dengan tiga tahapan, yaitu (i) penyediaan Arduino $I D E$, (ii) penetapan pin-pin pada port masukan/keluaran dan pembuatan algoritma, dan (iii) pengunggahan program dari $P C$ ke modul Arduino berbantuan kabel USB.

Penampungan air pada tandon air induk tidak boleh pada ketinggian (level) lebih kecil dari 50\% dan lebih besar dari $90 \%$ dari ketinggian permukaan air tandon air induk. Kesalahan pembacaan sensor ultrasonik HCSR04 terjadi saat level permukaan air terlalu rendah dan tinggi, karena pembacaan minimal sensor ultrasonik HC-SR04 tidak noleh kurang dari $2 \mathrm{~cm}$. Ketinggian permukaan air yang dapat terukur secara maksimal sebesar $95 \%$. Saat penghitungan perbandingan antara debit air terbaca oleh sensor dan terukur melalui gelas ukur, diperoleh hasil yang selalu berbeda. Nilai error dipengaruhi oleh kecepatan air yang dipompakan oleh pompa air, dengan kondisi pompa air bertekanan rendah saat ketinggian permukaan air lebih kecil dari $49 \%$. Sistem dapat digunakan untuk pemantauan pembacaan data dari sensor waterflow berbantuan ESP8266 terpantau pada web server berbasis aplikasi Thinkspeak melalui layaur smartphone.

Saran pengembangan terhadap penelitian ini, disarankan untuk penambahan proses komunikasi antara mikrokontroler dan sensor waterflow G1/2, sebelumnya dengan komunikasi serial dikembangkan dengan penggunaan jaringan Internet, sehingga pengiriman data tidak perlu lagi dengan kabel penghubung. Peng-inputan kuota air dan pemantauan dapat dikembangkan dari jaringan LAN menjadi jaringan World Area Network $(W A N)$. Penambahan kontrol air pada tandogalon air induk untuk penjagaan ketinggian permukaan air antara $80 \%$ hingga $90 \%$, agar kecepatan pemompaan air dalam kondisi konstan.

\section{Daftar Rujukan}

[1] M. H. Miraz, M. Ali, P. S. Excell, and R. Picking, "A review on Internet of Things (IoT), Internet of Everything (IoE) and Internet of Nano Things (IoNT)," 2015 Internet Technol. Appl. ITA 2015 Proc. 6th Int. Conf., pp. 219-224, 2015, doi: 10.1109/ITechA.2015.7317398.

[2] M. S. Farooq, S. Riaz, A. Abid, K. Abid, and M. A. Naeem, “A Survey on the Role of IoT in Agriculture for the Implementation of Smart Farming," IEEE Access, vol. 7, pp. 156237-156271, 2019, doi: 10.1109/ACCESS.2019.2949703.

[3] S. M. R. Islam, D. Kwak, M. H. Kabir, M. Hossain, and K. S. Kwak, "The internet of things for health care: A comprehensive survey," IEEE Access, vol. 3, pp. 678-708, 2015, doi: 10.1109/ACCESS.2015.2437951.

[4] M. Irmansyah, E. Efrizon, E. Madona, and R. Putra, "Perancangan Sistim Monitoring Parkir Mobil Berbasis Web," Elektron J. Ilm., vol. 10, no. 2, pp. 11-14, 2018, doi: 10.30630/eji.10.2.72.

[5] F. Christoulakis and K. Thramboulidis, "IoT-based integration of IEC 61131 industrial automation systems: The case of UML4IoT," IEEE Int. Symp. Ind. Electron., vol. 2016-November, pp. 322-327, 2016, doi: 10.1109/ISIE.2016.7744911.

[6] M. A. Ali, A. H. Miry, and T. M. Salman, "IoT Based Water Tank Level Control System Using PLC," Proc. 2020 Int. Conf. Comput. Sci. Softw. Eng. CSASE 2020, pp. 7-12, 2020, doi: 10.1109/CSASE48920.2020.9142067.

[7] S. R. Prathibha, A. Hongal, and M. P. Jyothi, "IOT Based Monitoring System in Smart Agriculture," Proc. - 2017 Int. Conf. Recent Adv. Electron. Commun. Technol. ICRAECT 2017, pp. 8184, 2017, doi: 10.1109/ICRAECT.2017.52.

[8] A. E. U. Salam, Muh, Tola, M. Selintung, and F. Maricar, "Web based real time water pressure monitoring system," Int. Conf. Electr. Eng. Comput. Sci. Informatics, vol. 1, no. August, pp. 223227, 2014, doi: 10.11591/eecsi.1.406.

[9] J. G. Natividad and T. D. Palaoag, "IoT based model for monitoring and controlling water distribution," IOP Conf. Ser. Mater. Sci. Eng., vol. 482, no. 1, pp. 0-6, 2019, doi: 10.1088/1757-899X/482/1/012045.

[10] L. Devy, Y. Antonisfia, M. Febrina, and S. Suryadi, "Sistem Pengendalian dan Monitoring Distribusi Air Berbasis Nodemcu 8266," Elektron J. Ilm., vol. 12, no. 1, pp. 16-23, 2020, doi: 10.30630/eji.12.1.153.

[11] S. Shankar and M. Dakshayini, "IoT-Mobile Enabled Smart Water Level Controlling System to Regulate Water Wastage," 2018 Int. Conf. Adv. Comput. Commun. Informatics, ICACCI 2018, pp. 2045-2048, 2018, doi: 10.1109/ICACCI.2018.8554373.

[12] R. Wahyuni, J. T. Sentana, M. Muhardi, and Y. Irawan, "Water Level Control Monitoring Based On Arduino Uno R3 Atmega 238 p Using Lm0161 LCD at STMIK Hang Tuah Pekanbaru," $J$. Robot. Control, vol. 2, no. 4, pp. 265-269, 2021, doi: 10.18196/jrc. 2489 .

[13] R. Triady and D. Triyanto, "Prototipe Sistem Keran Air Otomatis Berbasis Sensor Flowmeter pada Gedung Bertingkat," J. Coding Sist. Komput. Untan, vol. 03, no. 3, pp. 25-34, 2015.

[14] M. Baszynski and S. Pirog, "Unipolar Modulation for a BLDC Motor with Simultaneously Switching of Two Transistors with Closed Loop Control for Four-Quadrant Operation," IEEE Trans. Ind. Informatics, vol. 14, no. 1, pp. 146-155, 2018, doi: 10.1109/TII.2017.2723962.

15] D. B. Perkasa, T. Andromeda, and M. A. Riyadi, "Perancangan Perangkat Keras Alat Uji Bipolar Junction Transistor Berbasis Mikrokontroler," Transmisi, vol. 21, no. 1, p. 19, 2019, doi: 10.14710/transmisi.21.1.19-24.

[16] Indoware, "Ultrasonic Ranging Module HC - SR04," Datasheet, pp. 1-4, 2013, [Online]. Available: http://www.micropik.com/PDF/HCSR04.pdf.

[17] W.A. Akbar dan H.H. Rachmat. "Rancang Bangun Sistem Pengukur Massa Tubuh dan Panjang Badan Elektronik Terintegrasi untuk Evaluasi Gizi Balita," ELKOMIKA J. Tek. Energi Elektr. Tek. Telekomun. Tek. Elektron., vol. 6, no. 1, p. 125, 2018, doi: 10.26760/elkomika v6i1.125

DOI: https://doi.org/10.29207/resti.v5i6.3485

Lisensi: Creative Commons Attribution 4.0 International (CC BY 4.0) 